\title{
A multifactorial study of the resistance of honeybees Apis mellifera to the mite Varroa destructor over one year in Mexico ${ }^{1}$
}

\author{
Luis MONDRAGÓNa ${ }^{\mathrm{a}}$, Marla SPIVAK ${ }^{\mathrm{b}}$, Rémy VANDAME ${ }^{\mathrm{a} *}$ \\ a El Colegio de la Frontera Sur, Línea de Investigación “Abejas de Chiapas”, \\ Km 2.5 carretera Antiguo Aeropuerto, 30700 Tapachula, Chiapas, Mexico \\ b University of Minnesota, Department of Entomology, St. Paul, MN, USA
}

Received 24 June 2004 - revised 12 October 2005 - accepted 10 November 2005

Published online 7 July 2005

\begin{abstract}
A one year study was conducted to evaluate the population growth of three kinds of honey bee colonies and Varroa destructor mites in Mexico, and to estimate the relative contributions of three resistance mechanisms of the bees: hygienic behavior, grooming behavior, and reproductive ability of the parasite. Very significant changes over the year were observed in the number of mated female offspring produced per mother mite $(\mathrm{Wr})$, mite fertility and mutilation of $\mathrm{V}$. destructor. These changes were correlated to the total number of mites per colony. A factorial analysis showed that two mechanisms explained the variation in the amount of mites per colony: $W r\left(r^{2}=0.73\right)$ and proportion of mutilated mites $\left(r^{2}=0.51\right)$. A multi-factorial model including these two mechanisms was significant $\left(r^{2}=0.97\right)$. The mite fecundity and the hygienic behavior could not explain the population changes of the mite, and the different kinds of bees showed no differences in the expression of the resistance mechanisms.
\end{abstract}

Varroa destructor / Africanized honeybees / mite reproduction / hygienic behavior / grooming behavior / resistance / population growth

\section{INTRODUCTION}

The host-parasite relation between Apis mellifera L. and Varroa destructor Anderson and Trueman has become an interesting model to study the mechanisms used by social insects to defend themselves against parasites. Although the mite has caused severe losses of honeybee colonies and has eliminated wild bee populations in temperate climates (Webster and Delaplane, 2001), it does not appear to be a serious pest in regions of the world where the Africanized honey bees (AHB) exist. Low infestation levels of $V$. destructor in AHB have been reported and different mechanisms of resistance of the bees to the mite have been described (GuzmánNovoa et al., 1999). Although the term 'resist- ance' from a parasitological point of view implies a real cost to the host (Vandame et al., 2002), we use the term in a wider sense: any situation in which the $V$. destructor population is maintained at a level sustainable for the honey bees colonies. In this sense, resistance includes mechanisms of defense of the host, mechanisms of the parasite to avoid harming the host, or neutral (unselected) mechanisms.

On its original host, the Asian bee A. cerana Fabr., the mite is not a serious pest, because it does not reproduce successfully on worker brood (Koeniger et al., 1981). Consequently the total number of $V$. destructor within an A. cerana colony is always low $(<800)$. In AHB colonies, the mite can reproduce in worker brood cells, which are more abundant

\footnotetext{
* Corresponding author: rvandame@tap-ecosur.edu.mx
}

${ }^{1}$ Manuscript editor: Stefan Fuchs 
than drone brood cells, and $V$. destructor populations stabilize between 1000-3000 mites without killing the colonies (Vandame et al., 2000; Medina et al., 2002). In European honeybees (EHB), the mite populations are able to increase 4-fold annually in tropical regions (Vandame et al., 2000), causing colony death within one year because as few as 20003600 mites are enough to kill an EHB colony according to a model approached by Martin (2001) for honeybees from Europe.

There are several mechanisms used by honeybees to defend themselves against the parasite. A review by Guzmán-Novoa et al. (1999) in Mexico showed that EHB brood was twice as attractive to $V$. destructor than AHB brood, the removal of naturally infested brood in AHB was four times higher than in EHB, and AHB workers were more efficient in grooming mites from their bodies.

The reproductive success of $V$. destructor on AHB is highly variable. The best measure of successful reproduction in $V$. destructor is the number of mated female mite offspring produced in worker brood cells per foundress per reproductive cycle ( $\mathrm{Wr}$; Martin and Medina, 2004). This measure takes into account only the females that contribute to the population growth (Corrêa-Marques et al., 2003), since the mature female offspring have a high probability of having been mated (Donzé et al., 1996). Medina and Martin (1999), in a comparative study, found an important difference in the $W r$ in different countries: 0.73 for AHB in Mexico compared to 0.92 for EHB in the UK. This difference seems to partially account for the stabilization of the mite population growth in AHB between 1000-3000 individuals and an increase of $V$. destructor populations in EHB until the colony dies (Martin and Medina, 2004). In Brazil, low mite fertility (25-57\%; Martin et al., 1997) is reported to be responsible for bee resistance to $V$. destructor (Ritter and De Jong, 1984; Rosenkranz and Engels, 1994). Nevertheless, in AHB from Mexico, mite fertility does not seem to be the main reason for bee resistance because its level (83-96\%; Medina et al., 2002) is similar to the reported for EHB from Europe (76-94\%; Martin et al., 1997).

Hygienic behavior is considered a mechanism of resistance to Varroa through the bees' detection, uncapping and removal of infested pupae (Boecking and Spivak, 1999; Peng et al., 1987a). Vandame et al. (2000) found in Mexico that the EHB were able to remove only $8.0 \%$ of infested brood while AHB removed up to $32.5 \%$ showing a possible mechanism that could contribute to the tolerance of AHB toward $V$. destructor. At the same time, they described a natural seasonal cycle in the parasite population, but a relation between this phenomena and changes in hygienic behavior through time was not investigated. European colonies selected for hygienic behavior in the USA had lower mite levels and produced more honey than unselected colonies (Spivak and Reuter, 1998a, 2001); however, selection for hygienic behavior alone is not a sufficient resistance mechanism. Bees probably require multiple mechanisms to confer resistance; i.e., to survive without treatment.

Another mechanism of resistance is grooming behavior (Peng et al., 1987b). Through it, a worker bee is able to groom herself with her legs and mandibles to remove the mite and then injure it (Peng et al., 1987b). ArechavaletaVelasco and Guzmán-Novoa (2001) found in Mexico that the decrease in the mite infestation levels could be due to the proportion of injured mites within a random sample as result of grooming.

It is interesting to focus on the situation in Mexico, where many authors have studied the host/parasite relationship, but few studies have evaluated the effects of resistance mechanisms in a multifactorial way, through time and with naturally infested colonies.

The aims of the present study were thus (1) to estimate the changes of the population of mites and bees in honeybee colonies through an annual cycle, (2) to estimate the changes through time of hygienic behavior, grooming behavior, and reproduction of $V$. destructor in the same colonies, (3) to study if the defense mechanisms can explain, in a factorial and multifactorial way, the variation in the population of the parasite over time, and (4) to determine if honeybee colonies with European-hygienic queens and European commercial queens, naturally mated with Africanized drones, have different responses compared to AHB colonies in the aforementioned measures. 


\section{MATERIALS AND METHODS}

The study was conducted from February 2003 through January 2004, in an apiary near the city of

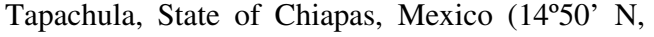
$92^{\circ} 16^{\prime} \mathrm{W}$ ). This region has a sub-humid tropical climate, an altitude of 120 meters, a mean annual temperature of $26^{\circ} \mathrm{C}$ (ranging from $19-39^{\circ} \mathrm{C}$ ), and a rainfall average of $1346 \mathrm{~mm}$ yearly (García, 1973). The rainy season runs approximately from May to October. The nectar flow begins almost one month after the end of the rains, finishing in March or April. The bees collect considerable amounts of pollen during the rainy season, particularly in August and September.

\subsection{Establishment of honey bee colonies}

In 1999, 30 feral colonies were sampled in the region of study and were analyzed morphometrically through the program USDA-ID 2.0 (Rinderer et al., 1993). According to this multivariate analysis, the projection on the first discriminant axis had a mean factor of $-2.12 \pm 1.13$, showing that the population was Africanized. Since no major introduction of bees in the region has occurred since then, the honeybee colonies used in this study most likely had the same level of Africanization as they did in 1999. Moreover, the colonies have never been treated to control $V$. destructor since the arrival of the mite in the region in 1994.

Five months before the beginning of the study several hygienic artificially inseminated and commercial European queens were imported from USA to Tapachula. The first ones came from the stock of selected hygienic queens developed at the University of Minnesota by Spivak and Reuter (1998a) and reared by a queen breeder (Glenn Apiaries, California). The second ones were imported from a commercial queen breeder in the US. These queens were used to rear daughters in the queen rearing station of Ecosur in Tapachula, and were naturally mated with Africanized drones. These daughters were the genetic source to form the two kinds of mixed colonies studied: European-hygienic $\times$ Africanized (EHA) and European-commercial $\times$ Africanized (ECA).

The study began with 46 colonies (16 AHB, 15 EHA and 15 ECA) in February 2003. Estimates of bee and mite populations, and resistance mechanisms were made in each colony every 5 weeks. This period corresponds to approximately two mites generations ( 12 days in worker cells and approximately 5 days on adult bees for each generation; Fries et al., 1994). In a preliminary study in the previous year, we detected a decrease in mite and bee populations in May, so we decided to make two estimates in May 2003. Thus, a total of ten samplings were made over 12 months.

\subsection{Bee population estimates}

Visual estimates of the comb area occupied by worker and drone sealed brood were made. Approximately 7000 worker brood cells fill a comb in AHB colonies; thus, we used a scale from 0 to 1 for each comb (0.1 units corresponding to approximately 700 cells). The same was done with drone brood cells, but making a correction of $1.4 \times$ ). The adult bee population was estimated visually using a scale from 1 to 5 , corresponding to 10000 to 50000 bees. This method was compared and validated with the ones used by Calis et al. (1999). All categorical variables were transformed into continuous variables for statistical analysis.

\subsection{Varroa population estimates}

At each sampling time, a sample of 150 to 200 bees was collected from the central brood frames of each hive into $70 \%$ ethanol to determine the percentage of infestation of mites on adult bees. At the same time, at least 100 worker and 30 drone brood cells were uncapped, to determine the proportion of mites in brood.

The total adult population of $V$. destructor was estimated by summing the estimated number of mites in brood (infestation level in brood $\times$ sealed brood) and the estimated number of mites on adults (infestation level on adult bees $\times$ adult bee population).

\subsection{Resistance mechanisms estimates}

\subsubsection{Hygienic behavior}

The hygienic behavior of each colony was measured using an assay described by Spivak and Reuter (1998b) in which approximately 150 cells containing sealed brood were freeze-killed with liquid nitrogen. The frames with the frozen brood were reintroduced in the hive and the amount of freeze-killed brood completely removed after $48 \mathrm{~h}$ was recorded.

\subsubsection{Mutilated mites}

As an estimator to evaluate a possible effect of grooming behavior, the proportion of mites with injured legs was measured following Ruttner and Hänel (1992). Because we observed several foundress mites with damaged idiosoma producing normal offspring, this type of injury was not considered. A paper smeared with shortening and protected by a mesh screen was placed on the bottom board of each colony for 48 hours. In the laboratory, 90 to 110 adult mites were collected from the paper, following the methods and precautions of Bienefeld 
et al. (1999). The proportion of mites with injured legs in the sample were recorded with the aid of a stereoscopic microscope.

\subsubsection{Varroa reproduction}

Samples of sealed worker brood $(5 \times 7 \mathrm{~cm}$ section approximately), older than 230 hours (gray pads stage, according to Martin, 1994) were collected at each sampling period and were immediately stored at $-5^{\circ} \mathrm{C}$. In the laboratory, from 100 to 300 cells were carefully opened. The pupae and the complete mite family of cells invaded by a single mother mite (Fuchs and Langenbach, 1989) were removed with a fine brush and examined at $10 \times$ in a microscope. Each $V$. destructor developmental stage was recorded using the ontogenic developmental charts in Martin (1994).

To determine the reproductive success of the mites, the following data were recorded: (1) percent of cells containing mother mites that reproduced (fertility), (2) total offspring per mother mite (fecundity), and (3) number of mated adult female offspring produced per mother mite $(\mathrm{Wr})$. Sometimes the offspring die before reaching the adult stage, and can be missed. If this was the case, a closer look within the cell, on the bee pupae or on the bee exuviae, revealed the presence of the dead mite or confirmed its absence. To determine if a female mite was adult, viable and mated, we used the presence of the following evidence: (a) an alive adult male, (b) the male and female exuviae shed from her body, (b) if the exuviae was not found, the color of the mite had to be from mid-light to dark brown, and her body was analyzed to ensure it was not still covered with its exuviae.

The methods for recording the three reproductive factors (fertility, fecundity and $W r$ ) are the same as those reported by Corrêa-Marques et al. (2003).

\subsection{Statistical analysis}

Of the initial 46 colonies, 18 (6 AHB, 6 EHA and 6 ECA) still contained the original queens and offered a complete set of data. For these 18 colonies, the estimators used to study the changes in bees and mites populations (including measure of resistance mechanisms) were analyzed separately using a repeated measures 2-way ANOVA (SPSS Inc, 1999) to determine variations through time and to define if some differences existed among the three type of honeybee colonies. Because the repeated sampling of the same honeybee colonies introduced considerable risk of temporal non-independence, we verified the absence of interaction among sample period and bee type (Underwood, 2001). The data obtained were checked for normality and arc-sin transformed data were used for percentage values.
Regression and correlation analyses were performed on the 18 surviving colonies to determine if the variation in mite population through time could be explained by any of the defense mechanisms studied. Finally, to study a possible multiple effect of the factors, a multifactorial analysis was performed (SPSS Inc, 1999).

\section{RESULTS}

\subsection{Colony survivorship and sample size for analysis}

Of the original 46 colonies, 25 survived until the end of the study, 18 of them with the original queens ( 6 of each bee type studied) and 7 with superseded queens. The other 21 colonies were lost for the following reasons: their population declined until the colonies died or absconded due to being highly infested with wax moths (6 colonies); the virgin queen died after the colony swarmed (4 colonies); or they absconded ( 11 colonies). We do not know if the mites were responsible for triggering the colonies to abscond. No chalkbrood or foulbrood was present in the dead colonies.

In a preliminary analysis, we found that there were no differences in the populations of bees and mites between the data sets when all the colonies were included and when only the 18 surviving colonies with the original queen were used. Therefore, only the 18 surviving colonies, six from each bee type, were analyzed.

\subsection{Honeybee population estimates}

Bee populations of the 18 colonies varied significantly through time, and among the three bee types (Fig. 1). The amount of sealed worker brood showed a natural decrease beginning in February (in the middle of the nectar flow), and reached a minimum value in the second half of May (at the beginning of the rainy season). It then increased to reach a maximum level in October (toward the end of rainy season). The adult bee population showed the same trend but with a lag time of one-sampling period.

Because the amount of drone brood in the colonies was highly variable or absent, it was not possible to perform an analysis of variance. Nevertheless, we observed an obvious decrease in drone brood in May because in 17 colonies it was absent; whereas from October to January 


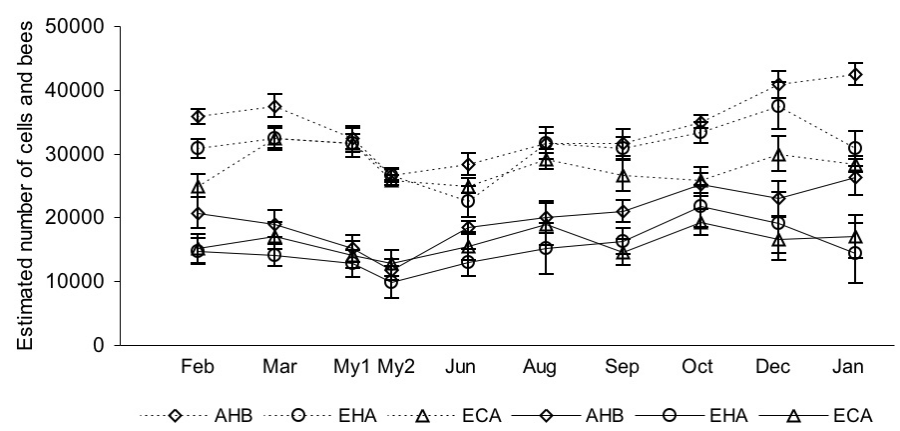

Figure 1. Estimated mean numbers $( \pm$ S.E.) of adult bees (dotted lines) and sealed worker brood cells (solid lines) for the 18 colonies studied $(\mathrm{AHB}=6, \mathrm{EHA}=6$, and $\mathrm{ECA}=6)$.

in 16 colonies drone brood was present. Mean annual number of drone pupae was $748.9 \pm$ 1219.6, with minimum and maximum means of $77.8 \pm 162.9$ and $1763.9 \pm 1783.2$ throughout the year.

\subsection{Mite population estimates}

Over the period of study, there was a natural decrease in mite populations, reaching significant minimum values in June and August and then increasing by more than a factor of three to reach maximum populations in December (Tab. I, Fig. 2). A significant interaction among sample period and bee type was found in the worker brood infestation level, but not in the estimated total number of mites (see Tab. I).

To analyze the variation in the total number of mites, we eliminated the data from February because we found an interaction between sample period and bee type in this month $(F=2.65$; $d f=18,150 ; P=0.001)$. The total number of mites varied significantly through time, and there was no variation among the different bee types. The mean annual number of mites ( \pm S.D.) per colony was of $3786.5 \pm 2444.2$. Although it was not possible to analyze the differences in drone brood infestation, the population growth of $V$. destructor was not different when the drone brood mite population was included, with slight exceptions during the first and the last months (Fig. 2).

\subsection{Resistance mechanisms estimations}

The AHB colonies removed significantly less freeze killed brood than the EHA and ECA colonies (Tab. II, Fig. 3). Overall, the colonies removed significantly more dead brood in August and less in January.

Levels of mutilated mites showed no differences among the three bee types, but there was a significant variation over the year, with a minimum level of injured mites in January, and maximum levels from May to September (Tab. II, Fig. 3).

In total, 2022 worker cells invaded by a single mother mite were analyzed to estimate the mite reproductive factors. Mite foundress fertility showed significant differences over the period of study, but not among bee types. The mean annual percentage of mites that reproduced was $85.5 \% \pm 15.5$, with a minimum level observed in June (Fig. 4). There were no differences in the mean number of offspring produced per mother mite through time, or among bee types. Mean fecundity was $4.1 \pm 0.7$ mites per mother. The number of mated female mite offspring produced per foundress mite $(\mathrm{Wr})$ showed highly significant differences over the year, but not among honeybee colonies. Mean annual $W r$ for all bee types combined was $0.88 \pm 0.423$ with a conspicuous period of minimal $W r$ in June and a maximum in February and October (see Tab. II for details and Fig. 4).

\subsection{Relation between mite population and resistance mechanisms}

We hypothesized that if the resistance mechanisms have an effect on mite population growth, their impact should be noted some time after their estimation, not immediately. Thus, we used the succeeding sampling period (a 
Table I. Mean values and differences in the bee colonies and mite population estimations between Africanized (AHB; $n=6$ ), hygienic European $\times$ Africanized (EHA; $n=6$ ), and commercial European $\times$ Africanized colonies (ECA; $n=6$ ) throughout the 10 sampling periods. Differences between mean values are based on an ANOVA and HSD Tukey's test $(P<0.05)$. Statistical tests are based on arc-sin transformed data of percentage values, but untransformed means and S.D. are expressed here $(\mathrm{Hb}=$ honeybee type; $\mathrm{Sm}=$ sampling period; $\mathrm{Hb} \times \mathrm{Sm}=$ interaction) .

\begin{tabular}{|c|c|c|c|c|}
\hline $\begin{array}{l}\text { Population } \\
\text { Estimator }\end{array}$ & $\begin{array}{c}\text { Honeybee } \\
\text { type }\end{array}$ & Annual mean \pm S.D. & & $\begin{array}{c}\text { Repeated measures } \\
\text { 2-way ANOVA }\end{array}$ \\
\hline Number of worker & All types & $17118.9 \pm 5790.5$ & & $\mathrm{Hb} F=18.5 ; d f=2,150 ; P<0.001$ \\
\hline \multirow[t]{3}{*}{ brood cells } & AHB & $20078.3 \pm 5806.5$ & a & $\operatorname{Sm} F=7.24 ; d f=9,150 ; P<0.001$ \\
\hline & EHA & $15143.3 \pm 5691.2$ & $\mathrm{~b}$ & $\mathrm{Hb} \times \operatorname{Sm} F=1.1 ; d f=18,150 ; P=0.361$ \\
\hline & ECA & $16135.0 \pm 4665.4$ & $\mathrm{~b}$ & \\
\hline Number of & All types & $31027.8 \pm 7524.6$ & & $\mathrm{Hb} F=14.0 ; d f=2,150 ; P<0.001$ \\
\hline \multirow[t]{3}{*}{ adult bees } & AHB & $34250.0 \pm 6878.2$ & a & $\operatorname{Sm} F=4.8 ; d f=9,150 ; P<0.001$ \\
\hline & EHA & $30833.3 \pm 8034.2$ & $\mathrm{~b}$ & $\mathrm{Hb} \times \operatorname{Sm} F=1.1 ; d f=18,150 ; P=0.348$ \\
\hline & ECA & $28000.0 \pm 6324.6$ & $\mathrm{c}$ & \\
\hline Adult bee & All types & $6.7 \pm 5.1$ & & $\mathrm{Hb} F=6.0 ; d f=2,150 ; P=0.003$ \\
\hline \multirow[t]{3}{*}{ infestation $(\%)$} & AHB & $5.6 \pm 3.9$ & a & $\operatorname{Sm} F=8.5 ; d f=9,150 ; P<0.001$ \\
\hline & EHA & $6.5 \pm 5.8$ & $\mathrm{bc}$ & $\mathrm{Hb} \times \operatorname{Sm} F=1.4 ; d f=18,150 ; P=0.122$ \\
\hline & ECA & $7.9 \pm 5.2$ & $\mathrm{c}$ & \\
\hline Worker brood & All types & $10.7 \pm 7.8$ & & $\mathrm{Hb} F=2.8 ; d f=2,150 ; P=0.064$ \\
\hline \multirow[t]{3}{*}{ infestation $(\%)$} & AHB & $9.0 \pm 5.8$ & a & $\operatorname{Sm} F=6.1 ; d f=9,150 ; P<0.001$ \\
\hline & EHA & $12.7 \pm 9.6$ & a & $\mathrm{Hb} \times \operatorname{Sm} F=2.6 ; d f=18,150 ; P=0.001$ \\
\hline & ECA & $10.5 \pm 7.3$ & a & \\
\hline Total number & All types & $3786.5 \pm 2444.2$ & & $\mathrm{Hb} F=2.3 ; d f=2,135 ; P=0.105$ \\
\hline \multirow[t]{3}{*}{ of mites } & AHB & $3713.0 \pm 2376.2$ & a & $\operatorname{Sm} F=12.9 ; d f=8,135 ; P<0.001$ \\
\hline & EHA & $3839.6 \pm 2835.1$ & a & $\mathrm{Hb} \times \operatorname{Sm} F=0.95 ; d f=16,135 ; P=0.516$ \\
\hline & ECA & $3806.8 \pm 2105.1$ & a & $(*)$ \\
\hline
\end{tabular}

(*) 2-way ANOVA on all sample periods data excluding that of February.

lapse of two mite generations) to evaluate the effects of resistance mechanisms on $V$. destructor population changes.

A positive correlation was found between $W r$ and the estimated number of mites in the succeeding sampling period $(r=0.855 ; P=$ $0.002 ; n=9)$, a simple linear regression analysis between these two variables showed a significant relationship explaining $73.2 \%$ of the variation $\left(r^{2}=0.732 ; P=0.003 ; n=9 ;\right.$ Fig. $\left.5 a\right)$. A positive correlation between fertility and estimated number of $V$. destructor per colony was found ( $r=0.718 ; P=0.015 ; n=9$ ); the simple linear regression analysis showed a signif- icant relationship where fertility explained $51.6 \%$ of the variation in total number of mites $\left(r^{2}=0.516 ; P=0.03 ; n=9 ;\right.$ Fig. $\left.5 b\right)$. A negative correlation was found between the proportion of injured mites and total number of mites in the colonies in the succeeding sampling period $(r=$ $-0.711 ; P=0.016 ; n=9)$. A linear regression between these two variables showed a significant relationship explaining $50.6 \%$ of the variation $\left(r^{2}=0.506 ; P=0.032 ; n=9\right.$; Fig. $\left.5 c\right)$. No significant correlation was found between hygienic behavior and total number of mites per colony in the next sampling period $(r=$ $0.03 ; P=0.469 ; n=9$ ). 


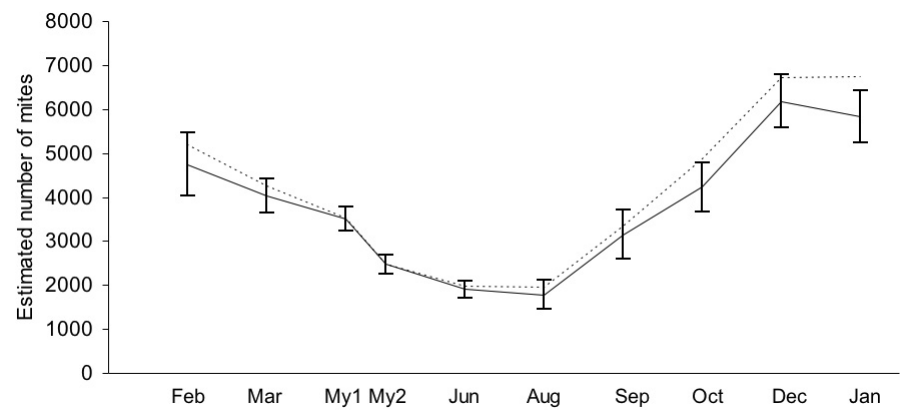

Figure 2. Estimated mean numbers ( \pm S.E.) of mites for the 18 colonies studied (solid line); the data are pooled since there was no significant difference between the three bee types. The mean number of mites including mites inside drone brood cells is also shown (dotted line).

Multiple regression analysis was performed considering $\mathrm{Wr}$ and mutilation level as independent variables, and the total number of mites per colony as the dependent variable. Fertility and hygienic behavior did not contribute to the significance of the model because the former showed high collinearity with $W r(r=0.911$; $P<0.0001 ; n=9)$, and hygienic behavior levels showed no significant partial correlation $(r=$ $-0.371 ; P=0.412 ; n=9)$. The multiple regression equation was $\mathrm{TNM}_{(\mathrm{t}+1)}=6242.9 \mathrm{Wr}_{(\mathrm{t})}-$ 118.2 $\mathrm{MM}_{(\mathrm{t})}$, where $\mathrm{TNM}_{(\mathrm{t}+1)}$ is the estimated total number of mites in the succeeding sample period, $W r$ is the number of mated female offspring, and MM is the level of mutilated mites $\left(r^{2}=0.973 ; P \leq 0.0001 ; n=9\right)$. The Constant value of the equation was not significant and was excluded from the regression equation $(t=$ $1.16 ; P=0.291)$. The results are showed in Table III. Tests to verify assumptions underlying the use of multiple regression analysis were performed and confirmed normality, independence between independent variables, and aleatority of residuals.

\section{DISCUSSION}

\subsection{Honeybee population}

There were seasonal variations in populations of the 18 surviving honeybee colonies. These variations were congruent with other studies conducted in Mexico (Echazarreta and Paxton, 1997; Vandame et al., 2000), although the peaks of maximum and minimum population were observed in different periods. Though we did not measure the pollen flow, it normally begins at the onset of the rainy season, reaching a maximum influx in August and September. The presence of pollen (from one to two full combs in some colonies) probably explain why the bee population increased in the rainy season. Although the EHA and ECA colonies had significantly less sealed worker brood than AHB colonies, they did not decrease to the extent that EHB do in tropical climates (Vandame et al., 2000). This probably means that the crosses (European queens mated to Africanized drones) have a similar fitness than AHB in the tropics.

\subsection{Mite populations}

Although initial and final values of $V$. destructor levels showed an apparent increase in the amount of mites from 4746 to 5843.45 , the repeated measures assay every 5 weeks, showed temporal trends. There was a decrease in the number of mites by a factor of 2.6 from February to August, and then an increase by a factor of 3.5 to reach the maximum value in December. The natural changes in mite populations throughout the year was similar to the one described in Mexico by Vandame et al. (2000), and Medina et al. (2002), showing that the year round brood production of AHB and mixed colonies in this study is not the critical factor responsible for continuous mite growth. When the mites in drone brood were included in the estimate of total mite levels, we found slight differences in the estimated mite population at the beginning and at the end of the study (see 
Table II. Mean values and differences in the resistance mechanisms studied among three honeybee types: Africanized (AHB), hygienic European $\times$ Africanized (EHA), and commercial European $\times$ Africanized (ECA). Differences between mean values are based on an ANOVA and HSD Tukey's test $(P<0.05)$. Statistical tests are based on arc-sin transformed data of percentage values, but untransformed means and S.D. are expressed $(\mathrm{Hb}=$ honeybee type; $\mathrm{Sm}=$ sampling period; $\mathrm{Hb} \times \mathrm{Sm}=$ interaction $)$.

\begin{tabular}{|c|c|c|c|c|c|}
\hline Mechanism & $\begin{array}{c}\text { Honeybee } \\
\text { type }\end{array}$ & $n$ & $\begin{array}{c}\text { Annual } \\
\text { Mean } \pm \text { S.D. }\end{array}$ & & $\begin{array}{c}\text { Repeated measures } \\
\text { 2-way ANOVA }\end{array}$ \\
\hline Hygienic Behavior & All types & 180 & $75.7 \pm 25.3$ & & $\mathrm{Hb} F=4.99 ; d f=2,150 ; P=0.008$ \\
\hline \multirow[t]{3}{*}{$(\%)$} & AHB & 60 & $67.9 \pm 28.6$ & a & $\operatorname{Sm} F=2.5 ; d f=9,150 ; P=0.011$ \\
\hline & EHA & 60 & $80.4 \pm 22.1$ & b & $\mathrm{Hb} \times \operatorname{Sm} F=1.15 ; d f=18,150 ; P=0.311$ \\
\hline & ECA & 60 & $78.7 \pm 23.4$ & b & \\
\hline Mutilated mites & All types & 175 & $15.1 \pm 10.0$ & & $\mathrm{Hb} F=0.324 ; d f=2,145 ; P=0.724$ \\
\hline \multirow[t]{3}{*}{$(\%)$} & AHB & 60 & $14.5 \pm 7.9$ & a & $\operatorname{Sm} F=2.99 ; d f=9,145 ; P=0.003$ \\
\hline & EHA & 57 & $14.7 \pm 10.2$ & $\mathrm{a}$ & $\mathrm{Hb} \times \operatorname{Sm} F=0.339 ; d f=18,145 ; P=0.995$ \\
\hline & ECA & 58 & $16.2 \pm 11.7$ & a & \\
\hline Number of Mated & All types & 178 & $0.88 \pm 0.42$ & & $\mathrm{Hb} F=0.23 ; d f=2,148 ; P=0.795$ \\
\hline \multirow[t]{3}{*}{ Female Offspring } & AHB & 60 & $0.89 \pm 0.43$ & a & $\operatorname{Sm} F=4.63 ; d f=9,148 ; P<0.001$ \\
\hline & EHA & 59 & $0.90 \pm 0.43$ & $\mathrm{a}$ & $\mathrm{Hb} \times \operatorname{Sm} F=1.12 ; d f=18,148 ; P=0.342$ \\
\hline & ECA & 59 & $0.86 \pm 0.42$ & a & \\
\hline \multirow[t]{4}{*}{ Fertility (\%) } & All types & 178 & $85.5 \pm 15.5$ & & $\mathrm{Hb} F=0.84 ; d f=2,148 ; P=0.434$ \\
\hline & AHB & 60 & $83.9 \pm 17.3$ & a & $\operatorname{Sm} F=3.04 ; d f=9,148 ; P=0.002$ \\
\hline & EHA & 59 & $87.0 \pm 15.6$ & $\mathrm{a}$ & $\mathrm{Hb} \times \operatorname{Sm} F=1.04 ; d f=18,148 ; P=0.418$ \\
\hline & ECA & 59 & $85.6 \pm 13.3$ & a & \\
\hline \multirow[t]{4}{*}{ Fecundity } & All types & 178 & $4.1 \pm 0.7$ & & $\mathrm{Hb} F=0.32 ; d f=2,148 ; P=0.726$ \\
\hline & AHB & 60 & $4.2 \pm 0.9$ & a & $\operatorname{Sm} F=1.04 ; d f=9,148 ; P=0.415$ \\
\hline & EHA & 59 & $4.1 \pm 0.7$ & a & $\mathrm{Hb} \times \operatorname{Sm} F=1.23 ; d f=18,148 ; P=0.247$ \\
\hline & ECA & 59 & $4.1 \pm 0.6$ & $\mathrm{a}$ & \\
\hline
\end{tabular}

Fig. 2). Nevertheless, the growth of mite population in drone brood must be studied with care because of a possible density dependant mechanism that actually may limit mite growth (Martin and Medina, 2004).

Though there were significant differences in the estimates of bee populations among the three bee types, there were no differences in the number of mites among them. The average number of mites per colony was 3786 and was higher than the numbers estimated by Vandame et al. (2000) (1513 mites) and Medina et al. (2002) (2380 mites). These differences can be attributed to the stronger populations of honeybee colonies used in our study, and to the mean annual $W r$ of 0.88 per mother, higher than the $W r$ found by Medina et al. (2002) of 0.73 .

\subsection{Resistance mechanisms}

\subsubsection{Hygienic behavior}

Only those honeybee colonies that remove more than $95 \%$ of dead freeze killed brood in 48 hours are considered highly hygienic (Spivak and Gilliam, 1993) and only highly hygienic colonies may express the behavior to a degree where it could function as a resistance mechanism to control the mite populations. None of the colonies in the present study could be considered highly hygienic because the mean annual percent removal of freeze-killed brood was lower than $85 \%$ for every bee type, and was always less than $95 \%$ for every sample period (Fig. 3). This could be the reason why 


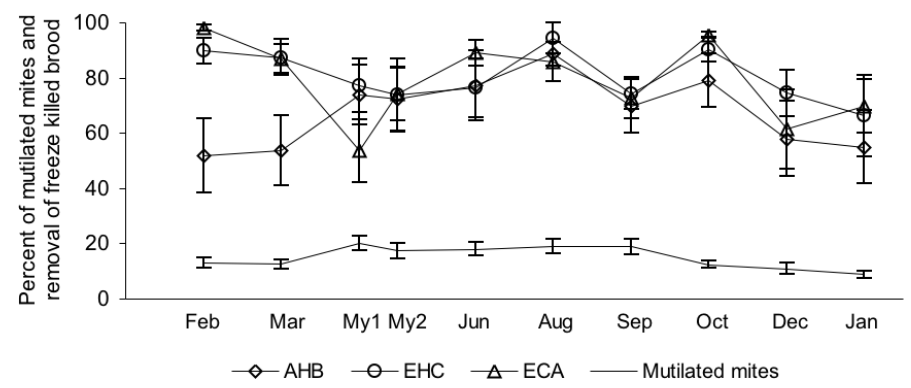

Figure 3. Mean levels $( \pm$ S.E.) of hygienic behavior and mutilated mites for the 18 colonies studied $(\mathrm{AHB}=6, \mathrm{EHA}=6, \mathrm{ECA}=6)$. Mean levels of mutilated mites are pooled because there were no significant differences among the three bee types.

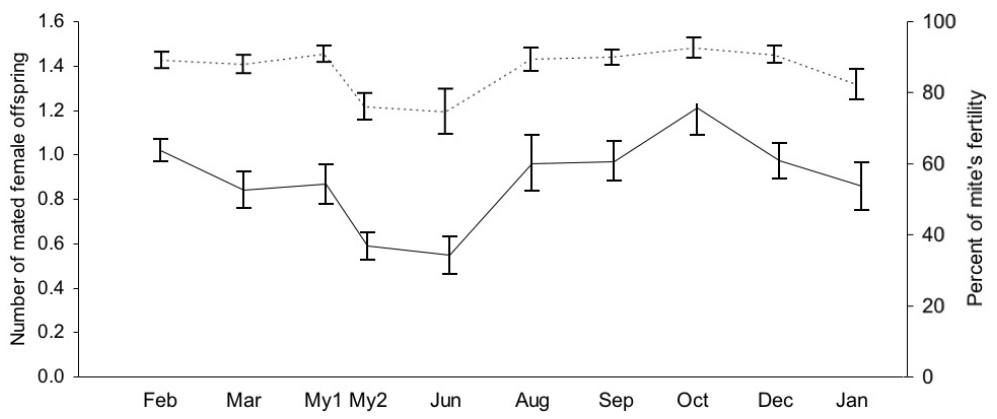

Figure 4. Mean number of mated female mite offspring ( \pm S.E.) produced per foundress mite (solid line) and mean level of foundress mite fertility $( \pm$ S.E.) (dotted line) for the 18 colonies studied; the data are pooled since there was no significant difference between the three bee types.

we did not find a significant correlation between hygienic behavior and fluctuations of mites throughout the year.

Hygienic behavior showed significant variations through time but with no evident trends. The highest level of dead brood removal was observed in August when colonies had relatively low populations of bees and mites, and when there was no honey flow. This observation does not correspond with the idea that the expression of hygienic behavior depends on colony strength and environmental conditions such as honey flow (Spivak and Gilliam, 1993).

Based on the results of Guzmán-Novoa et al. (1999) and Vandame et al. (2002), we expected that the most hygienic colonies would be the EA, followed by the AHB, and then by the ECA. Nevertheless AHB colonies removed significantly less freeze killed brood than ECA, and both types of mixed colonies showed no differences between them (Tab. II; Fig. 3).
Because hygienic behavior is an heritable (Harbo and Harris, 1999) and recessive trait (Rothenbuhler, 1964), it is probably that the worker progeny from the EHA and ECA colonies were not hygienic because the mother queens encountered and reproduced with non hygienic Africanized drones. Thus, the AHB present in the zone in this year (the source of reproductive drones), may have a different hygienic response than the AHB reported in other studies.

\subsubsection{Grooming}

The annual average percent of mutilated $V$. destructor observed in this study (15.1\%) was similar to the percent reported for other AHB colonies in Mexico (14.9\%) (Vandame et al., 2002). We observed the highest number of mutilated mites from May to September, which corresponded with the decrease in $V$. destructor 

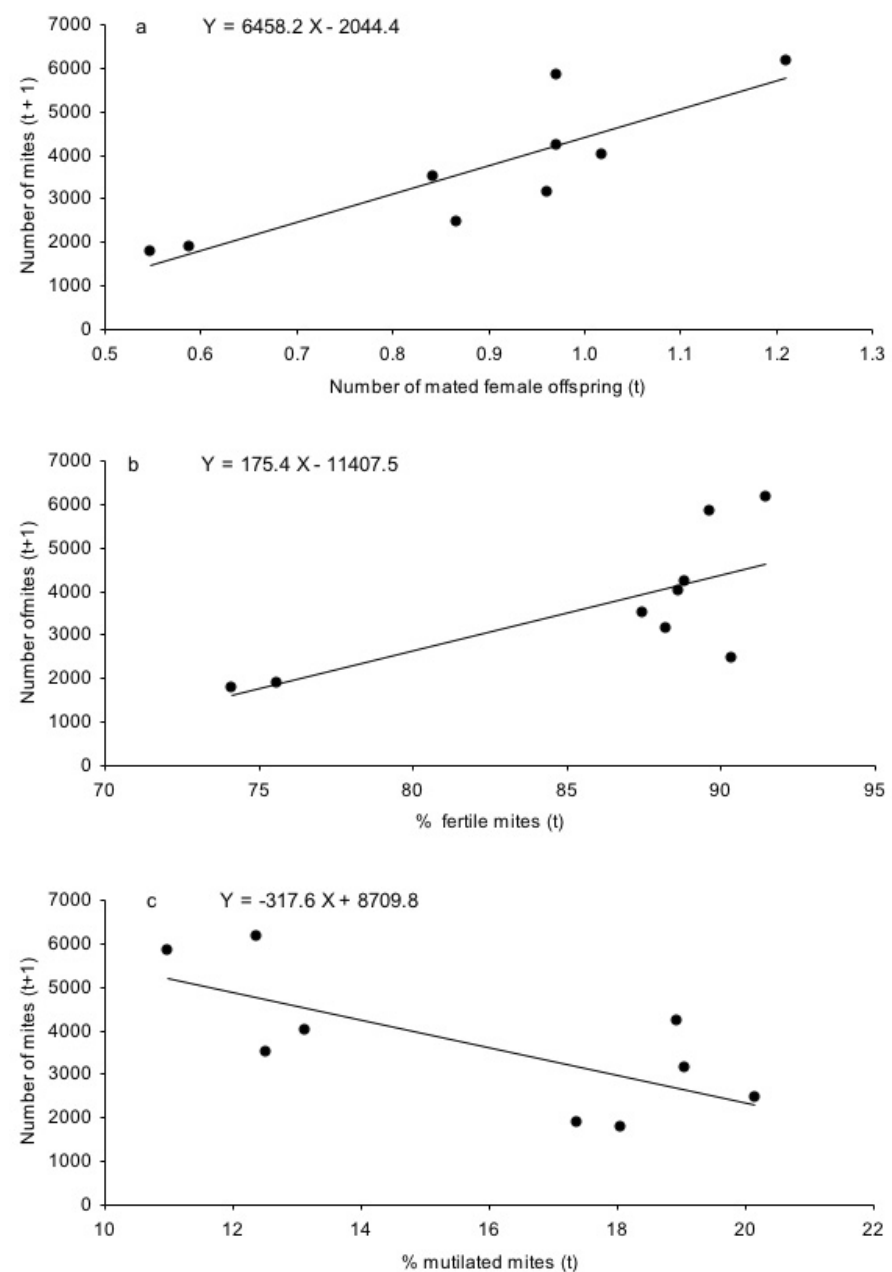

Figure 5. Relationship between the mean number of mites per colony in the succeeding sampling period $(t+1)$, and (a) the mean number of mated female mite offspring; (b) the mean percent of mites fertility; (c) the mean level of mutilated mites.

populations. The lowest level of injured mites (January) coincided with a period of highest number of mites. The simple regression analysis showed that $50.6 \%$ of the variability in the amount of $V$. destructor could be explained by the level of damaged mites. Thus, if we assume that the mite mutilations are due to grooming behavior, this factor may be an important contribution to the resistance of honeybees to the mite in the colonies studied. Nevertheless, the results must be interpreted with care because a random damage to the mite, not caused by the bees, may generate an overestimation of damage actually due to grooming.

\subsubsection{Mite reproduction}

The annual mean percentage of mites that reproduced was $85.5 \%$ with a range from 74.1 to $91.5 \%$, similar to that reported in other studies in Mexico with AHB and EHB: 83-96\% (Medina et al., 2002) and 82-97\% (Vandame et al., 1999), but higher than in AHB colonies in Brazil: 25-57\% (Martin et al., 1997). The simple regression analysis showed that $51.6 \%$ of the number of mites could be explained by the variation in mite fertility (Fig. 5). Nevertheless, a significantly low fertility level was found only in June, the month prior to when the 
Table III. Multiple regression analysis. The total number of mites per colony in the next sampling period is explained by the number of mated female offspring produced per mother and the mutilation level (grooming behavior) as independent variables.

\begin{tabular}{|c|c|c|c|c|c|}
\hline \multirow{2}{*}{$\begin{array}{l}\text { Independent } \\
\text { variable }\end{array}$} & \multirow{2}{*}{$\begin{array}{l}\text { Partial correlation } \\
\text { coefficient }\end{array}$} & Unstandardized & Coefficients & \multirow[t]{2}{*}{$\mathrm{t}$} & \multirow[t]{2}{*}{$P$} \\
\hline & & Beta & S.E. & & \\
\hline Number of mated female offspring & 0.961 & 6242.9 & 683.5 & 9.13 & $<0.0001$ \\
\hline Mutilation level & -0.760 & -118.2 & 38.3 & -3.1 & 0.017 \\
\hline
\end{tabular}

lowest number of mites were estimated. We suppose that this drop in mite fertility had a conspicuous effect when the mite population was already declining.

The average number of eggs laid per mother mite observed in this work was similar to that found in AHB from Mexico (Medina and Martin, 1999) and EHB from UK (Martin, 1994): 4.11, 4.86 and 4.93 respectively. Because there was no variation in fecundity through time, this factor could not explain the tolerance of honeybees toward the mite.

This is the first study in which changes in $\mathrm{Wr}$ through time are reported in a tropical region. The mean annual $W r$ was 0.88 and fell between the values found in EHB from UK (1.01) and AHB from Yucatan, Mexico (0.73), but was much higher than the ones found in AHB from Brazil (0.64) (Corrêa-Marques et al., 2003).

The number of mites per honeybee colony over the year was highly related to the $W r$ found in the previous sampling period, an interval corresponding to two mite generations. The minimum and maximum $W r$ were observed in June and October ( 0.55 and 1.21 respectively), and the periods with increased or decreased amount of mites per colony were found in the succeeding sampling months (August and December respectively) (Figs. 2 and 4). These observations were confirmed by the results found in the simple regression analysis because the fluctuations in the $\mathrm{Wr}$ explained $73.2 \%$ of the variability in the amount of mites per honeybee colony in the succeeding sampling period.

\subsection{Multifactorial study of the resistance}

The multiple regression analysis showed that $W r$ and grooming behavior expressed as the level of mutilated mites were the factors that best explained the variability in the total number of mites. Based on the simple regression model coefficients, we excluded fertility from the multifactorial analysis because this factor was less important in explaining the growth in mite population, and presented high collinearity with $W r$. We found a significant equation where the variation in total number of mites could be explained as follows: over the span of two mite generations, a 0.1 decrease in the $W r$ contributed to a reduction of the mite population by a magnitude of 624 individuals, while a $1.0 \%$ increase in the proportion of mutilated mites reduced the number of mites in a colony by a magnitude of 118 individuals.

The present study is the first and successful intent to explain Varroa resistance in a multifactorial way for AHB and AHB $\times$ EHB colonies in a tropical region. Our results showed that the addition of genes through Africanized males helps to confer resistance to European honeybees by means of changes in $\mathrm{Wr}$ and grooming behavior. One other multifactorial study by Branco et al. (1999) found three variables that explained the population growth of $V$. destructor. However, the variables they studied (probability of each mite to find a free larva on which to reproduce, occurrence of mite migration and mite death rate) were not related to the resistance mechanisms reported here and the work was done with EHB in a Mediterranean climate.

It is important to determine which factors produce changes in $W r$ to understand fully the variation in reproduction of $V$. destructor through time. Harris et al. (2003), analyzed the changes in population growth of $V$. destructor in EHB colonies during a 10-year period. They mentioned that diminished reproductive rates in mites could be the cause of reduced growth rates during periods of hot and dry weather. It is possible that some changes in the environmental variables within and external to honeybee colonies have effects on the development 
of immature mite offspring and on $W r$. In a further study we will present details of the mite's reproductive biology in AHB colonies that permit a determination of which kind of changes occur in the development of mite offspring.

\section{ACKNOWLEDGMENTS}

We are very grateful to Stephen Martin for his personal training in the analysis and study of Varroa reproduction, to Glenn Apiaries for providing hygienic queens, and to Omar Argüello, Agustín Méndez and Miguel Cigarroa for their great help in the field work. L. Mondragón was granted by CONACYT during his Ph.D. studies, and the work was supported by a grant from Fondo Mixto CONACYT / Gobierno del Estado de Chiapas.

Résumé - Étude multifactorielle de la résistance des abeilles domestiques, Apis mellifera, à l'acarien Varroa destructor sur une année au Mexique. Nous avons mené une étude afin d'évaluer la croissance de la population de Varroa destructor dans des colonies d'abeilles africanisées et dans deux types de colonies mixtes (européenne hygiénique $\times$ africanisée et européenne commerciale $\times$ africanisée) au Mexique. La contribution relative des trois mécanismes qui confèrent aux abeilles la résistance à l'acarien a été estimée toutes les cinq semaines durant une année.

Sur les 46 colonies d'origine, 18 colonies, dont six de chaque type, ont survécu jusqu'à la fin de l'étude avec leur reine d'origine. Les mesures des mécanismes de résistance ont été évalués par les protocoles suivants : (i) comportement hygiénique (pourcentage de couvain tué par le froid éliminé), (ii) comportement de toilettage (proportion d'acariens mutilés sur un plateau de fond enduit de matière grasse), (iii) capacité de reproduction du parasite par la fertilité (proportion d'acariens qui se reproduisent), (iv) fécondité (nombre total de descendants par fondatrice) et (v) nombre de descendants femelles fécondées produites par fondatrice $(\mathrm{Wr})$.

Les populations d'abeilles et d'acariens des 18 colonies ont varié de façon significative en fonction du temps et des trois types d'abeilles (Figs. 1 et 2). Des changements significatifs au cours de l'année ont été observés pour $W r$, la fertilité et la mutilation des acariens (Figs. 3 et 4 ). Ces changements correspondaient aux variations du nombre estimé d'acariens par colonie. Des différences significatives en fonction de la période de l'année et du type d'abeilles ont été trouvées pour le comportement hygiénique (Fig. 3), bien qu'aucune des colonies n'ait pu être considérée comme fortement hygiénique, puisque l'élimination du couvain mort a toujours été inférieure à $95 \%$. Le comportement hygiénique ne correspondait aux fluctuations des populations d'abeilles ou d'acariens.
Nous émettons l'hypothèse que si les mécanismes de résistance ont un effet sur la croissance de la population d'acariens, l'effet se fera sentir dans la période d'échantillonnage suivante (cinq semaines plus tard) et pas immédiatement. L'analyse factorielle a montré que les deux mécanismes rendaient compte de la variation d'acariens par colonie au cours du temps : $W r\left(r^{2}=0,732 ; P=0,003 ; n=9 ;\right.$ Fig. 5 a $)$ et de la proportion d'acariens mutilés $\left(r^{2}=0,506 ; P=\right.$ 0,$032 ; n=9$; Fig. 5 c). Quand on inclut ces deux mécanismes, on trouve un modèle multi-factoriel significatif $\left(r^{2}=0,973 ; P=0,0001 ; n=9\right)$. Aucune différence n'a été observée entre les abeilles africanisées et les colonies d'abeilles croisées dans le degré d'expression des mécanismes de résistance.

Varroa destructor / reproduction / abeille africanisée / comportement hygiénique / comportement de toilettage / résistance / dynamique de population

Zusammenfassung - Eine einjährige multifaktorielle Studie über die Resistenz der Honigbienen Apis mellifera gegen die Milbe Varroa destructor in Mexiko. Das Populationswachstums von Varroa destructor wurde in einer Studie während eines Zeitraums von einem Jahr in Mexiko bestimmt, und zwar bei afrikanisierten Bienenvölkern und bei zwei unterschiedlichen Volkstypen: (a) hygienisch europäisch $\times$ afrikanisierte Völker und (b) kommerzielle europäische $\times$ afrikanisierte Völker. Drei Mechanismen und ihr relativer Beitrag zur Resistenz gegen die Milbe wurde alle 5 Wochen über ein Jahr verteilt untersucht.

Von den ursprünglich 46 Völkern überlebten bis zum Ende des Versuchs 18 mit ihren Originalköniginnen, sechs aus jeder Versuchsgruppe. Messungen der Resistenzmechanismen wurden folgendermaßen durchgeführt: 1. Hygieneverhalten (\% Entfernung von durch Einfrieren getöteter Brut); 2. Putzverhalten (Anteil von verletzten Milben auf einer klebrigen Unterlage) und 3. die Reproduktionsfähigkeit der Parasiten, unterteilt in (a) Anteil der reproduzierenden Milben, (b) Gesamtzahl der Nachkommen pro Muttermilbe, und (c) Zahl von begatteten weiblichen Nachkommen pro Muttermilbe $(W r)$.

Die Population der Bienen und Milben in den 18 Völkern veränderte sich signifikant während der Versuchszeit, außerdem unterschieden sich die 3 Versuchstypen der Bienen signifikant in Bezug auf die Volksstärke (Abb. 1 und 2).

Signifikante Änderungen während des Jahres gab es bei der Nachkommenzahl pro Milbe und der Verletzung von $V$. destructor (Abb. 3 und 4). Diese Änderungen entsprachen den berechneten Schwankungen der Milbenzahl pro Volk. Signifikante Unterschiede während des Jahres und zwischen den 3 Bienentypen wurden beim Hygieneverhalten gefunden (Abb. 3). Keines der Völker wies ein sehr gutes Hygieneverhalten auf (die Entfernung toter 
Brut war immer geringer als $95 \%$ ), trotzdem stand das Hygieneverhalten nicht in Relation zu Veränderungen im Volk oder der Milbenpopulation.

Wir stellen folgende Hypothesen auf: Wenn Resistenzmechanismen einen Einfluss auf das Wachstum der Milbenpopulation haben, ist dieser Effekt nicht sofort sondern erst in der folgenden Untersuchungsperiode ( 5 Wochen später) nachzuweisen. Eine faktorielle Analyse zeigte, dass zwei Mechanismen die Variation der Menge der Milben pro Volk über längere Zeit erklärt: die Zahl von begatteten weiblichen Nachkommen pro Muttermilbe $\left(r^{2}=0,732 ; P=\right.$ 0,$003 ; n=9$; Fig. 5a) und der Anteil der verletzten Milben $\left(r^{2}=0,506 ; P=0,032 ; n=9\right.$; Fig. 5 c) . Ein signifikantes multifaktorielles Modell wurde gefunden $\left(r^{2}=0,973 ; P=0,0001 ; n=9\right)$, wenn diese beiden Mechanismen enthalten waren. Es ergaben sich keine Unterschiede zwischen den beobachteten afrikanisierten und den gekreuzten Völkern in der Stärke der Resistenzmechanismen.

Varroa destructor / afrikanisierte Honigbienen / Milbenvermehrung / Hygieneverhalten / Putzverhalten / Resistenz / Populationswachstum

\section{REFERENCES}

Arechavaleta-Velasco M.E., Guzmán-Novoa E. (2001) Relative effect of four characteristics that restrain the population growth of the mite Varroa destructor in honey bee (Apis mellifera) colonies, Apidologie 32, 157-174.

Bienefeld K., Zautke F., Pronin D., Mazeed A. (1999) Recording the proportion of damaged Varroa jacobsoni Oud. in the debris of honey colonies (Apis mellifera), Apidologie 30, 249-256.

Boecking O., Spivak M. (1999) Behavioral defenses of honey bees against Varroa jacobsoni Oud., Apidologie 30, 141-158.

Branco M.R., Kidd N.A.C., Pickard R.S. (1999) Development of Varroa jacobsoni in colonies of Apis mellifera iberica in a Mediterranean climate, Apidologie 30, 491-503.

Calis J.N.N., Fries I., Ryrie S.C. (1999) Population modeling of Varroa jacobsoni Oud., Apidologie 30, 111-124.

Corrêa-Marques M.H., Medina L.M., Martin S.J., De Jong D. (2003) Comparing data on the reproduction of Varroa destructor, Genet. Mol. Res. 2, 1-6.

Donzé G., Herrmann M., Bachofen B., Guerin P.M (1996) Effect of mating frequency and brood cell infestation rate on the reproductive success of the honeybee parasite Varroa jacobsoni, Ecol. Entomol. 21, 17-26.

Echazarreta C.M., Paxton R.J. (1997) Comparative colony development of Africanized and European honeybees (Apis mellifera) in lowland neotropical Yucatan, Mexico, J. Apic. Res. 36, 89-103.
Fries I., Camazine S., Sneyd J. (1994) Population dynamics of Varroa jacobsoni: a model and a review, Bee World 75, 5-28.

Fuchs S., Langenbach K. (1989) Multiple infestation of Apis mellifera L. brood cells and reproduction in Varroa jacobsoni Oud., Apidologie 20, 257266.

García E. (1973) Modificación al sistema climático de Köeppen, Instituto Nacional de Geografía, UNAM, Mexico.

Guzmán-Novoa E., Vandame R., Arechavaleta M.E. (1999) Susceptibility of European and Africanized honey bees (Apis mellifera L.) to Varroa jacobsoni Oud. in Mexico, Apidologie 30, 173182.

Harbo J.R., Harris, J.W. (1999) Heritability in honey bees (Hymenoptera: Apidae) of characteristics associated with resistance to Varroa jacobsoni (Mesostigmata: Varroidae), J. Econ. Entomol. 92, 261-265.

Harris J.W., Harbo J.R., Villa J.D., Danka R.G. (2003) Variable population growth of Varroa destructor (Mesostigmata: Varroidae) in colonies of honeybees (Hymenoptera: Apidae) during 10year period, Environ. Entomol. 32, 1305-1312.

Koeniger N., Koeniger G., Wijayagunasekar N.H.P. (1981) Anpassung von Varroa jacobsoni an ihren natürlichen wirt Apis cerana in Sri Lanka (Observations about the adaptation of Varroa jacobsoni on its natural host Apis cerana in Sri Lanka), Apidologie 12, 37-40.

Martin S.J. (1994) Ontogenesis of the mite Varroa jacobsoni Oud. in worker brood of the honeybee Apis mellifera L. under natural conditions, Exp. Appl. Acarol. 18, 87-100.

Martin S.J. (2001) The role of Varroa and viral pathogens in the collapse of honeybee colonies: a modelling approach, J. Appl. Ecol. 38, 10821093.

Martin S.J., Medina L.M. (2004) Africanized honey bees have unique tolerance to Varroa mites, Trends Parasitol. 20, 112-114.

Martin S.J., Holland K., Murray M. (1997) Nonreproduction in the honeybee mite Varroa jacobsoni, Exp. Appl. Acarol. 21, 539-549.

Medina L.M., Martin S.J. (1999) A comparative study of Varroa jacobsoni reproduction in worker cells of honey bees (Apis mellifera) in England and Africanized bees in Yucatan, Mexico, Exp. Appl. Acarol. 23, 659-667.

Medina L.M., Martin S.J., Espinosa L.M., Ratnieks L.F.W. (2002) Reproduction of Varroa destructor in worker brood of Africanized honey bees (Apis mellifera), Exp. Appl. Acarol. 27, 79-88.

Peng Y.S., Fang Y., Zu S., Ge L., Nasr M.E. (1987a) Response of foster Asian honey bee (Apis cerana Fabr.) colonies to the brood of European honey bees (Apis mellifera L.) infested with parasitic 
mite Varroa jacobsoni Oudemans, J. Invertebr. Pathol. 49, 259-264.

Peng Y.S., Fang Y., Xu S., Ge L. (1987b) The resistance mechanisms of the Asian honey bee Apis cerana Fabr., to an ectoparasitic mite, Varroa jacobsoni Oudemans, J. Invertebr. Pathol. 49, 54-60.

Rinderer T.E., Buco S.M., Rubink W.L., Daly H.V., Stelzer J.A., Riggio R.M., Baptista F.C. (1993) Morphometric identification of Africanized and European honey bees using large reference populations, Apidologie 24, 569-585.

Ritter W., De Jong D. (1984) Reproduction of Varroa jacobsoni O. in Europe, the Middle East and tropical South America, Z. Angew. Entomol. 98, 55-57.

Rosenkranz P., Engels W. (1994) Infertility of Varroa jacobsoni females after invasion into Apis mellifera worker brood as tolerance factor against varroatosis, Apidologie 25, 402-411.

Rothenbuhler W.C. (1964) Behaviour genetics of nest cleaning in honey bees. IV. Responses of F1 and backcross generations to disease-killed brood, Am. Zool. 4, 111-123.

Ruttner F., Hänel H. (1992) Active defense against Varroa mites in Carniolan strain of honeybee (Apis mellifera carnica Pollmann), Apidologie 23, 173-187.

Spivak M., Gilliam M. (1993) Facultative expression of hygienic behaviour of honey bees in relation to disease resistance, J. Apic. Res. 32, 147-157.
Spivak M., Reuter G.S. (1998a) Performance of hygienic colonies in a commercial apiary, Apidologie 29, 285-296.

Spivak M., Reuter G.S. (1998b) Honey bee hygienic behavior, Am. Bee J. 138, 283-286.

Spivak M., Reuter G.S. (2001) Varroa destructor infestation in untreated honey bee (Hymenoptera: Apidae) colonies selected for hygienic behavior, J. Econ. Entomol. 94, 326-331.

SPSS Inc. (1999) Applications Guide, Base 10.0, Chicago IL, USA.

Sumpter D., Martin S.J. (2004) The dynamics of virus epidemics in Varroa infested honey bee colonies, J. Anim. Ecol. 73, 51-63.

Underwood A.J. (2001) Experiments in Ecology. Cambridge University Press, Cambridge, UK.

Vandame R., Colin M.E., Otero-Colina G. (1999) Africanized honeybees tolerance to Varroa in Mexico: mite infertility is not the main tolerance factor, Apiacta 34, 1-5.

Vandame R., Colin M.E., Morand S., Otero-Colina G. (2000) Levels of compatibility in a new hostparasite association: Apis mellifera/Varroa jacobsoni, Can. J. Zool. 78, 2037-2044.

Vandame R., Morand S., Colin M.E., Belzunces L.P. (2002) Parasitism in the social bee Apis mellifera: quantifying costs and benefits of behavioural resistance to Varroa mites, Apidologie 33, 433455.

Webster T.C., Delaplane K.S. (2001) Mites of the Honey Bee, Dadant publications, Illinois. 